\title{
Strategies of social (re)production within international higher education: The case of Swiss hospitality management schools (7954 words)
}

Anne-Sophie Delval, Institute of Sociology, Faubourg de l'hôpital 27, University of Neuchâtel, Neuchâtel, Switzerland

Felix BühImann, Institute of Social and Political Science, University of Lausanne, Lausanne, Switzerland

\section{Abstract (215 words)}

Globalisation has led to the transformation of the field of higher education, including an increase in international students' mobility and new offers of internationalised educational curricula "at home." This evolution provides new opportunities for both intentional and non-intentional strategies of educational internationalisation, which are a potentially important part of the social mobility and reproduction of the middle and upper classes. This article investigates the students of Swiss hospitality management schools (SHMSs) - institutions of higher education that are often privately run and characterised by a high degree of internationalisation. We explore the configurations of these students' "cosmopolitan capital" (a combination of cultural, linguistic and social assets acquired through transnational mobility or exposure to an international environment), and we ask how these configurations vary with regards to their social backgrounds, specifically concerning their proximity to the cultural versus the economic pole of the class structure. We carried out a multiple correspondence analysis of three dimensions of cosmopolitan capital of 381 students, used cluster analysis to identify five configurations of cosmopolitanism and then tested for the social characteristics of these students' parents by using a multinomial regression model. Our results showed various strategies of the accumulation, conversion and legitimation of cosmopolitan capital, and they emphasised the role that this form of capital plays in the mobility and reproduction strategies of these students' families.

\section{Introduction}

Scholars have intensely investigated how globalisation affects educational policies, institutions and students of higher education (Altbach et al., 2009). Globalisation, characterised by an increasingly integrated world economy, new information and communications technologies, the emergence of an international knowledge network and the predominance of English as lingua franca (Altbach et al. 2009), contributed to the rapid growth of transnational student mobilities and led to a sharper 
international competition between educational institutions (Altbach 1999; Altbach et al. 2009; Willoughby 2008; Marginson 2006). However, the ability to move through the internationalised system of higher education and to make a profit from it depends on the socioeconomic and geographic origins of students (Igarashi and Saito 2014; Börjesson 2017). Studying abroad, especially at the most prestigious universities internationally, is still a privilege of students with upper-class backgrounds (Findlay et al. 2012). At the same time, higher education institutions also tend to prepare local students, from wider class backgrounds, to work in the global economy (Robson 2011). They integrate "international and intercultural dimensions into the formal and informal curriculum for all students within domestic learning environments" (Beelen and Jones 2015). Furthermore, an "international education sector," which offers curricula in English and is prone to welcome foreign students, has become an important actor in the field of higher education over the past few decades (Findlay 2010). As a consequence, through transnational mobility, and by seizing local opportunities "at home" (De Wit 2011; Robson et al. 2018), specific social groups have developed - potentially but not necessarily intentional (Bourdieu, 1993) - strategies of educational internationalisation "in pursuit of social, economic, political or cultural benefits" (Mitchell \& Nielsen 2012 pp.9-10).

Swiss hospitality management schools (SHMSs) are a good case for studying the educational strategies of internationalisation used within private systems of higher education. According to various rankings ${ }^{1}$, SHMSs - such as Ecole hôtelière de Lausanne, Les Roches and Glion - are among the most renowned hospitality management schools globally. They enjoy a good reputation within the global hospitality and tourism industries by providing practical and theoretical training in hospitality management. Unlike "regular" higher education institutions in Switzerland (such as universities), almost all SHMSs are private and belong to industrial associations or international educational groups. Therefore, large portions of their revenues stem from student fees. In 2018, a diploma cost between 23,000 and 174,900 Swiss francs depending on the institution, the degree and the student's migratory status (Swiss residents pay lower fees). Most SHMSs teach in English or require a certain level of English proficiency. Every year, about 17,000 transnational students (crossing national boundaries to study in Switzerland) and local students (staying in Switzerland after graduating from high school) attend these schools. Depending on the establishment, the share of transnational students varies between $30 \%$ and $100 \%$. Consequently, this international microcosm provides an environment in which students can acquire cosmopolitan competences, such as multilingualism, intercultural mindsets or the ease of travelling internationally (Robson 2011), which later can become assets for occupational careers (Draelants and Ballatore 2014; Petzold and Peter 2015).

\footnotetext{
${ }^{1}$ Eduniversal, CEOWORLD, hospitalitymanagementdegrees.net, EDUCATIONS.COM, QS Top Universities, SOFRES.
} 
In this study, we argue that an analysis of these schools and their students can provide insight into the transformation of the strategies of the social mobility and social reproduction of specific social groups. First, we determine how various groups of students distinguish themselves in terms of inherited "cosmopolitan capital," which is a combination of cultural, linguistic and social resources acquired through transnational mobility or exposure to international environments (Weenink, 2007, Wagner, 2011; Bühlmann et al. 2013). We argue that the attendance of a SHMS can be considered to be a potentially but not necessarily intentional (Bourdieu, 1993) - strategy for acquiring, converting or reinforcing one's equipment with cosmopolitan capital. Second, we raise the question of whether various configurations of cosmopolitan capital are related to the positions of students' parents in terms of class hierarchy and class fraction (cultural versus economic fraction). The data for this paper were derived from a questionnaire that 381 students from six SHMSs completed in 2016. Using multiple correspondence analysis (MCA), we draw a space of internationality and mobility. Next, we identify, using a cluster analysis, five types of student profiles that express various configurations of cosmopolitan capital. We then analyse the social backgrounds of the students in these configurations and develop a framework for a series of strategies of social mobility and social reproduction based on the use of cosmopolitan capital.

\section{Literature on educational internationalisation}

Strategies of educational internationalisation can occur at every stage of the curriculum, from primary schools to universities. However, most scholars studied transnational student mobility in higher education and argued that studying abroad in the most prestigious global institutions allows upper classes to preserve a comparative advantage (Waters 2006; Wagner 2011; Findlay et al. 2012). There are hints that mobility competence and multilingualism are gaining increasing importance in the recruiting decisions of top managers (Bühlmann et al. 2018). Employers view the ability to move as a sign of geographical and cultural flexibility that is integral to occupying international positions (Draelants and Ballatore 2014). Consequently, new educational offers are created or transformed to respond to this demand for "international goodwill" (Petzold and Peter 2015; Nogueira and Aguiar 2008). For example, at the primary and secondary levels, the most prestigious private schools in dominant countries accept foreign students and advertise themselves as "international" (Brooks and Waters 2015; Khan 2011). International boarding schools - which have been recruiting from a small number of dominant countries for a long time - have gradually begun to accept children from emerging countries (Bertron 2018). As a result, elites from new economic powers are choosing transnational educational mobility at early ages to acquire the linguistic, intellectual and behavioural dispositions needed to gain admittance to the most prestigious universities (Xiang and Shen 2009). 
Recently, scholars began to investigate settings where students can take part in international education - education in another language, with a diploma delivered from another country and with an international student body - within their countries of origin and remain "non-mobile" or "at home" (Beelen and Jones 2015; Robson et al. 2018; Hall and Appleyard 2011; Leung and Waters 2013; Almeida et al. 2018). At the higher education level, numerous institutions - mostly from the United Kingdom and the United States - have opened branches in other countries to export their educational offers (Levatino 2017). These forms of transnational education respond to the demand of students who do not have the academic and financial means to move to attractive destination countries (Leung and Waters 2013).

At the primary or secondary level, educational offers that were first designed for the children of expatriate communities and international managers (Wagner 1998) have come to gradually cater to pupils from local middle or upper classes (Weenink 2007; Forsberg et al. 2017). For example, "national schools abroad" propose national educational curricula and are establishments situated outside of their countries of origin-for example, "French schools" (Lycée Français) or "German schools" (Deutsche Auslandschule). In contrast, "International schools" (i.e., the International Baccalaureate, APA) teach mostly in English and propose their own curricula and diploma systems (Dugonjic-Rodwin 2014; Resnik 2012b, 2012a).

\section{Theoretical framework}

\subsection{Educational internationalisation and strategies of social mobility and reproduction}

The development drawn in this literature raises the question of the functions that educational internationalisation plays in the social reproduction of the upper classes (Waters et al. 2011; Carlson 2013; Findlay et al. 2012; King et al. 2011; Waters 2012; Xiang and Shen 2009). According to Bourdieu and Passeron (Bourdieu 1989; Bourdieu and Passeron 1970, 1964), the systems of higher education as the principal vector of the acquisition of institutional cultural capital - contribute substantially to the reproduction of the social structure (Bourdieu 1979). Coated with a meritocratic ideology, cultural capital legitimises access to dominant occupational positions. They argued that the competences required at the best schools correspond to the cultural capital that the children of upper-middle-class parents inherit. Additionally, the offspring of the economic pole of the field of power (such as managers) tend to attend business schools ${ }^{2}$, whereas the children of parents at the cultural pole (such

\footnotetext{
${ }^{2}$ Such as the Haute École commerciale (HEC) or the ESSEC in the French case.
} 
as intellectual professions) attend establishments that provide cultural capital ${ }^{3}$ (Bourdieu 1989). The system of higher education enables the upper classes to convert inherited capital into an institutionalised cultural form and to reproduce the opposition between economic and cultural elites in the field of power (Bourdieu 1989). The choice of a specific establishment and training represents a mode of social reproduction. In our case, we understand strategies of educational internationalisation as educational options for acquiring international credentials - through transnational student mobility and/or international education - that allows students to gain access or maintain membership in the upper classes. These educational strategies can be intentional but do not necessarily have to be. According to Bourdieu, they are "objectively oriented towards goals that may not be the goals subjectively pursued by the agents" (1993, p.76).

\subsection{The three dimensions of cosmopolitan capital}

We consider that both transnational and international educational experiences help with acquiring a specific form of capital. Several terms are used in the sociological literature to define it: "capital of mobility" (Murphy-Lejeune 2002), "international capital" (Wagner 2011, 1998; Wagner and Réau 2015), "cosmopolitan capital" (Bühlmann et al. 2013; Igarashi and Saito 2014; Weenink 2007) and "motility" (Kaufmann et al. 2004). Their common core theme is that transnational mobility endows individuals with skills, knowledge and dispositions that constitute resources for pursuing a geographically and socially mobile trajectory (Weenink 2008, 2007; BühImann et al. 2013).

Cosmopolitan capital is often already "inherited," and its accumulation begins at a very young age. For instance, Murphy-Lejeune (2002) showed that most Erasmus students lived abroad, possessed mixed nationalities and spoke several languages. Consequently, this type of capital is often reinforced by international schooling, which provides an institutional and consecrated form to the cultural resources of this specific group (Wagner 1998). Mobile students are part of an expanding group of transnationally mobile individuals and families, who speak foreign languages and have mixed family origins, whose lives are impacted by specific international lifestyles (Wagner 1998). However, living in an international culture does not necessarily mean that an individual's connection to a national context is severed; on the contrary, the most mobile groups often manage to remain locally rooted despite (or even because of) their very international orientation.

In this paper, we define cosmopolitan capital as a combination of cultural, linguistic and social resources acquired through transnational mobility or exposure to an international environment. The volume of this capital varies depending on the number and types of transnational and international

\footnotetext{
${ }^{3}$ Such as Ecole normale supérieure
} 
experiences. In a period of increasing globalisation, the acquisition and accumulation of cosmopolitan capital may become a new strategy of distinction and class reproduction. The access to cosmopolitan capital and the capacity to profit from it are not the same for all classes and citizens of various countries (Igarashi and Saito 2014). We assume that reflecting their parents' class positions, most of the students engaging in international higher education have already inherited certain forms of cosmopolitan capital during their childhoods.

The first dimension of cosmopolitan capital is the international character of one's education. This includes both the attendance of schools abroad and the attendance of international schools in one's home country (Findlay et al. 2012; Brooks and Waters 2015; Wagner 1998). International schooling can take multiple forms depending on the types of diplomas delivered, the diversity of the student body and the teaching language (Dugonjic-Rodwin 2014; Resnik 2012b). We consider international education to be an institutionalised and cultural dimension of cosmopolitan capital that signifies membership in the mobile upper classes.

The second dimension describes transnational mobility. Research has shown that students moving abroad for their tertiary education often build on preceding types of transnational mobility (MurphyLejeune 2002). The frequency of long-term relocations is the first indicator of a person's migration profile. Relocation experiences and longer stays abroad demonstrate that an individual has faced acculturation challenges and can settle in another country. Furthermore, transnational mobility may reveal multiple abilities related to the migratory activity, such as knowing how to depart or settle down. Although certain individuals experience linear and grounded migration from a home country to a host country, others go through circular and constant mobility.

The third dimension concerns institutionalised forms of cosmopolitan capital mirrored by the nationalities and the opportunities of mobility and establishment related to them. Sayad (1991) argued that the treatment of foreign citizens, depending on their national origins, reflects the political and economic hierarchies among countries. Possessing certain nationalities can provide specific access to the country of destination - for instance, in terms of residence rights or administrative procedures (Wagner 1998). This dimension expresses the political aspect linked to the circulation of persons and the regimes of student migration (Riano et al. 2018). Immigration policies can favour the transnational mobility of students from neighbour countries (or countries from the same political union of states) and slow the migration of people from third countries. In addition, having the nationality of the destination country makes it possible to reduce educational fees. 


\subsection{Research questions}

The geographical diversity of SHMS student populations and the international character of their education constitute an excellent case for delineating the various forms of educational internationalisation. Three questions guided our analysis:

1) What types of configurations of cosmopolitan capital exist among the students of SHMSs? How do these configurations vary in terms of the three dimensions of cosmopolitan capital discussed above (international education, mobility and institutional internationality)?

2) What are the social backgrounds of the parents of students of SHMSs (parents' highest occupational positions, educational levels of parents with the highest occupational positions) in terms of class hierarchy and class fraction (cultural versus economic fraction)?

3) What aspects of their parents' social backgrounds (e.g., class, education and occupational situations) can explain the membership of SHMS students in specific configurations of cosmopolitan capital?

The results of this study will provide insight into how students from various social backgrounds internationalise their education profiles to stay (or become) socially and geographically mobile. In the context of the internationalisation of higher education, we interpret the attendance of SHMSs - and private international higher education in general - as (intentional or unintentional) strategies of the social reproduction of the middle and upper classes throughout the world.

\section{Methods and Data}

In this section, we explain the methodological strategy we used, describe the data on which our study is based and depict the variables we used.

\subsection{Methodological strategy}

To analyse the inherited forms of cosmopolitan capital possessed by the students of SHMSs, we first realised a specific Multiple correspondence analysis (MCA). MCA uses a geometrical data analysis approach that allows one to study the relationship between categorical variables and to describe the relations of proximity and opposition among individuals (Le Roux 2014). A multi-dimensional geometrical space, represented by a cloud of points, summed the distribution of individuals in terms of their responses to active questions. This draws a bi-dimensional space where SHMSs' students are close to or distant from each other depending on the similarity of their answers concerning various aspects of their cosmopolitan capital. 
To identify configurations of cosmopolitan capital, we then carried out a cluster analysis on the coordinates of the first two axes of the cloud of individuals that the specific MCA created. For this purpose, we used ascending hierarchical clustering (Ward) based on Euclidian distances (Le Roux 2014). This enabled us to group the individuals who shared most of the modalities and to separate those who were the most different from one another. Based on a dendogram, we chose to retain five clusters.

As in the course of the analytical process, we discovered that belonging to a cluster varies depending on parents' occupations as well as their levels and types of education. In a third step, to link the configurations of cosmopolitan capital to the students' social backgrounds, we conducted a multinomial regression analysis. This method enabled us to identify the factors (e.g., sex, type of education and occupational position) explaining cluster membership.

\subsection{Sampling and Data}

Because no public statistics on SHMSs were available, we collected our data via a questionnaire. First, we identified 19 hospitality management schools in Switzerland. Among these 19 schools, we managed to negotiate the circulation of a questionnaire with six schools that vary according to their tradition richness (older versus more recently founded schools), their sizes (small versus large schools), their funding (public versus private schools), their teaching languages (English versus Swiss national languages) and the types of diplomas they deliver (educational level, internationality of the degrees). These six schools accurately depicted the diversity of the schools in Switzerland's educational market and covered the central cleavages in the field of SHMSs (Table 1).

Table 1: Characteristics of the SHMSs in our sample (2016)

\begin{tabular}{|c|c|c|c|c|c|c|}
\hline Name & Year of foundation & \# students & Status & Language & $\begin{array}{l}\text { Type of } \\
\text { diploma }\end{array}$ & $\mathbf{N}$ \\
\hline $\begin{array}{l}\text { Ecole hôtelière } \\
\text { de Lausanne }\end{array}$ & 1893 & 2,000 & $\begin{array}{l}\text { Private, subsidies } \\
\text { for Swiss students }\end{array}$ & $\begin{array}{l}\text { English \& } \\
\text { French }\end{array}$ & $\begin{array}{l}\text { Bachelor } \\
\text { (national + } \\
\text { international) }\end{array}$ & 170 \\
\hline Les Roches & $\begin{array}{l}1954 \text { (international } \\
\text { school) } \\
1979 \text { (hotel school) }\end{array}$ & 1,324 & $\begin{array}{l}\text { Private, } \\
\text { international group }\end{array}$ & English & $\begin{array}{l}\text { Bachelor } \\
\text { (international) }\end{array}$ & 20 \\
\hline $\begin{array}{l}\text { Ecole hôtelière } \\
\text { de Genève }\end{array}$ & $\begin{array}{l}1914 \text { (schools for } \\
\text { landlords) } \\
1996 \text { (hotel school) }\end{array}$ & 250 & $\begin{array}{l}\text { Private, subsidies } \\
\text { for Swiss students }\end{array}$ & French & $\begin{array}{l}\text { Specialised } \\
\text { school } \\
\text { (vocational / }\end{array}$ & 58 \\
\hline
\end{tabular}


national)

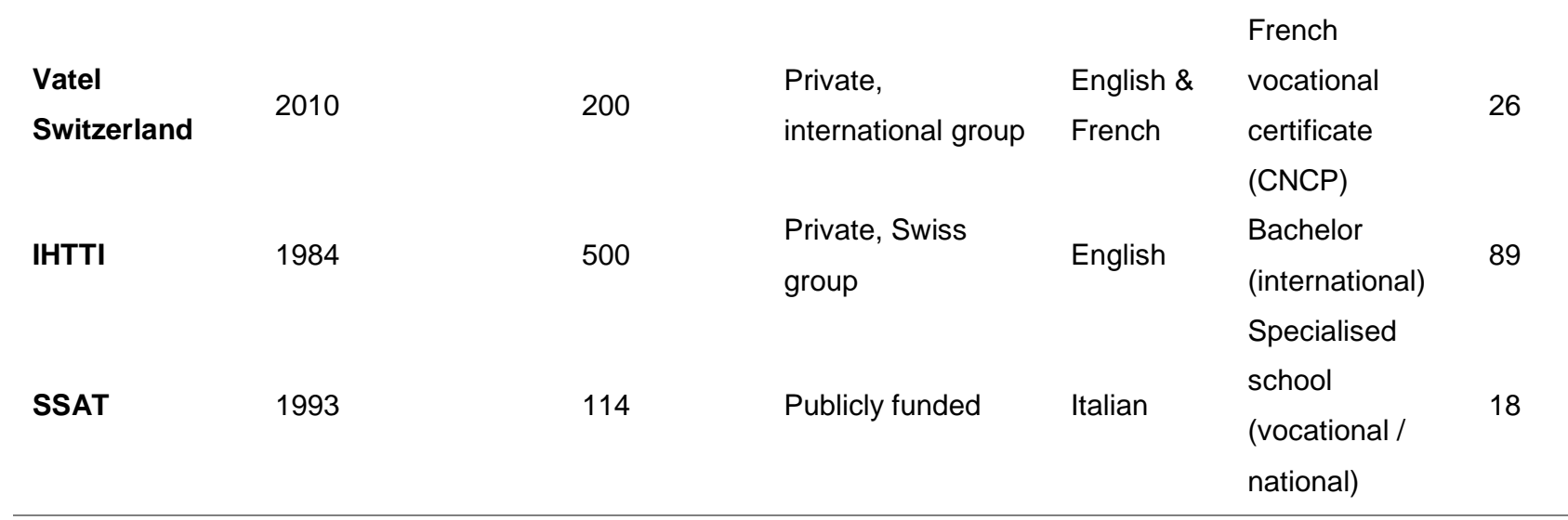

The English online questionnaire was completed by 381 students in March and September 2016. Our data constituted a first attempt to sample a group of SHMS students and had a reasonable degree of representativeness: Female students were overrepresented by $68.2 \%$ (compared with $56.2 \%$ in those six schools), and Swiss students were slightly underrepresented (with $39.1 \%$ versus $44.8 \%$ ). The average age of our sample was 21.3 years, whereas it was 22.1 years for all students at these schools.

\subsection{Variables}

Our survey comprised 69 questions about migratory and educational trajectories, the decision to attend a hotel school in Switzerland, living conditions, occupational aspirations, the social backgrounds of students (parental occupation, level and type of education) and sociodemographic characteristics.

To operationalise the cosmopolitan capital of SHMS students, we considered the three dimensions previously defined ${ }^{4}$ :

1) To measure the type and internationality of the education, we chose four variables: the type of diploma (occupational, national academic or international academic), the status of the educational establishment (public versus private), the internationality of the student population (local students or international students) and the teaching language (local or national language, English or another foreign language).

2) For transnational mobility, the focus was on the experience of mobility during childhood and youth, as well as linguistic competences. Three variables were used: the number of languages spoken $(2,3,4$ or more), moving to other countries between primary school and secondary

\footnotetext{
${ }^{4}$ These are the "active variables" of our MCA; see Table 9.1 in the appendix.
} 
school (sedentary versus mobile) and the number of relocations between countries of at least one year until the age of 18 years $(0,1,2,3$ or more)

3) The institutional form of cosmopolitan capital was measured by nationalities and preceding residencies: possessing Swiss nationality (yes or no), the number of nationalities $(1,2,3$ or more) and the country where a secondary school diploma was received (Switzerland, a neighbour country, another European Union [EU] country or a non-EU country).

To operationalise students' social backgrounds, we took into account the information of the parent with the highest occupational position (Erikson 1984). As these backgrounds were heavily skewed towards the upper classes, our scale was rather detailed on the upper end and rough on the lower end. We distinguished between "executives and entrepreneurs," "liberal professions" employed," "intellectual professions and middle management" and "intermediate professions, lower management and employees." In addition, we measured the educational level and educational discipline of the same parent (with the highest occupational position) with a mixed category: "human and social sciences (HESS)," "economics and business," "law and medicine," "engineering and natural sciences" and "no university."

\subsection{Limits of the study}

Even though SMHS are an interesting case for studying new strategies of educational internationalisation, we should be cautious not to overgeneralize our results. SHMSs are only one type of international institution that attracts a particular economic fraction of the middle and upper classes. Other institutions may focus on more cultural fractions or on vertically different strata of the class hierarchy. Other studies would be welcome that use larger and more comprehensive samples, as well as qualitative material to deepen our understanding of the internationalised strategies of the mobility and reproduction of the middle and upper classes.

\section{Main findings}

\subsection{The field of SHMS students}

We interpreted the first two axes of the MCA, which constituted $90.4 \%$ of the overall variance. The modified rates of $71.4 \%$ (axis 1) and 19.0\% (axis 2) provided an accurate bi-dimensional representation (Figure 1), where modalities close to each other were frequently shared by students with similar response patterns.

\footnotetext{
${ }^{5}$ In our survey, we detailed "liberal profession" by the following examples: lawyer, architect, psychologist and doctor.
} 
Table 2: Eigenvalues and modified rates of axes 1-5

\begin{tabular}{lccccc}
\hline & Axis 1 & Axis 2 & Axis 3 & Axis 4 & Axis 5 \\
Eigenvalue & 0.309 & 0.200 & 0.136 & 0.120 & 0.114 \\
Modified rate & $71.4 \%$ & $19.0 \%$ & $4.0 \%$ & $2.0 \%$ & $1.4 \%$ \\
Cumulative rate & $71.4 \%$ & $90.4 \%$ & $94.4 \%$ & $96.4 \%$ & $97.8 \%$ \\
\hline
\end{tabular}

Only the variables and categories above the average contribution were retained (average contribution of variables: $1 / 10=0.1$, average contribution of categories: $1 / 28=0.04$ ). Each category's contribution to the two axes is shown in Table 7 (appendix).

Figure 1: Multiple correspondence analysis of SHMS students

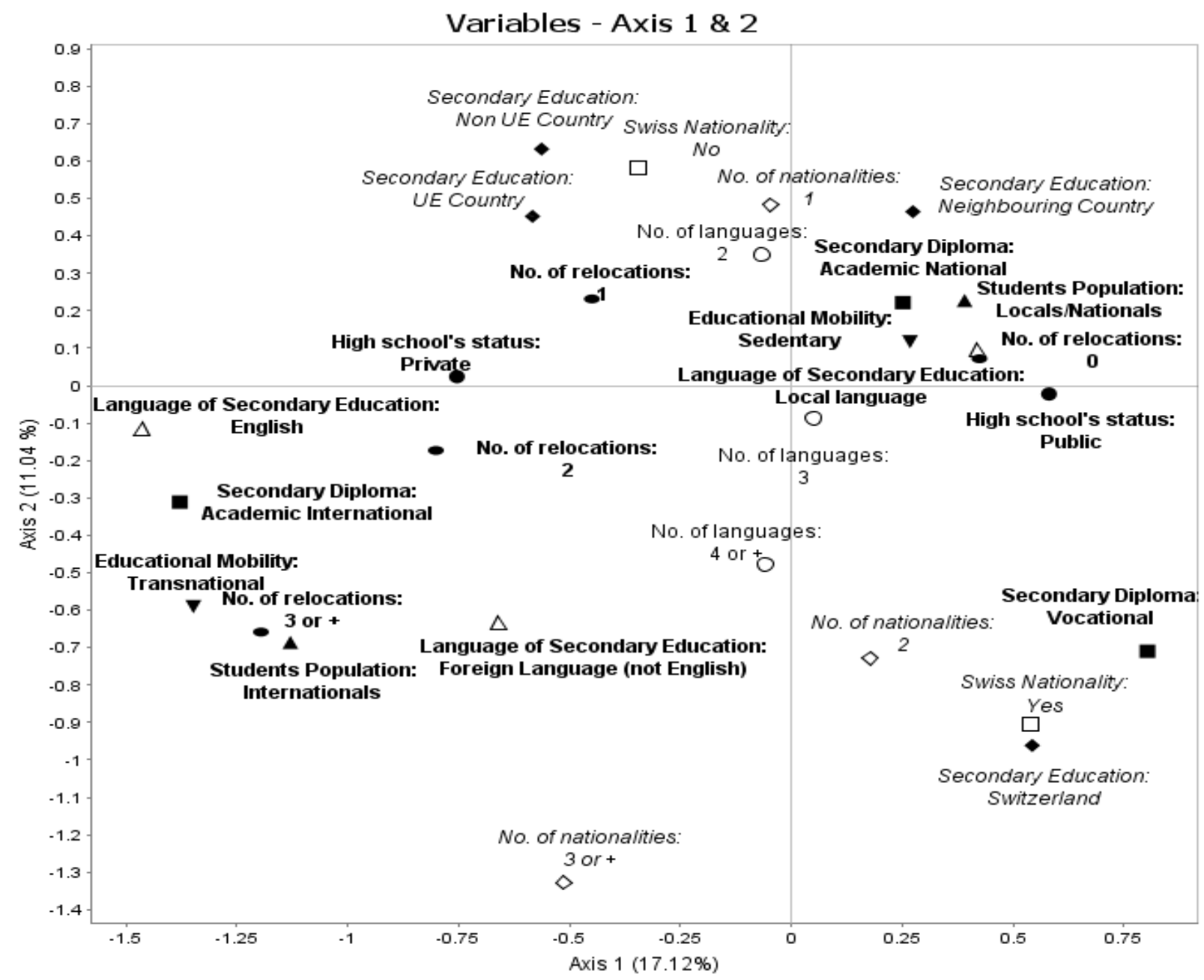

$\square$ Secondary Diploma: High school's status: $\boldsymbol{\Delta}$ Students Population: $\square$ Swiss Nationality: $\bullet$ No. of relocations: O No. of languages: $\mathbf{\nabla}$ Educational Mobility: $\triangle$ Teaching language: $\diamond$ No. of nationalities: $\diamond$ Secondary Education: 
The following six variables contributed $84.7 \%$ to the variance of axis 1 : the teaching language in secondary education (17.6\%), the type of secondary II diploma (16.1\%), the status of the establishment in secondary education (14.0\%), the internationality of the student population (13.9\%), educational mobility (11.6\%) and the number of transnational relocations (11.5\%). Eleven categories contributed 78.2\% to the variance of axis 1: On the left side, we find English as a teaching language in secondary education (12.2\%), international academic diploma (12.1\%), international studentship (10.3\%) and private establishment (7.8\%). In addition, relocation between primary and secondary education (9.7\%), and having experienced three relocations or more during childhood (4.7\%) are in the left space. On the right side are the following: attendance of a public establishment (6.2\%), education in a national language (4.2\%) and education with local students (3.6\%). Having Swiss nationality $(3.7 \%)$ and a sedentary childhood (3.7\%) are on the right as well. The first axis distinguishes students according to the internationality of their educational capital.

Three variables contributed to $73.1 \%$ of the variance on axis 2 : nationality $(26.3 \%)$, the country where the diploma of secondary education was obtained $(26.3 \%)$ and the number of nationalities $(20.5 \%)$. Seven categories contributed to $69.9 \%$ of the variance: In the upper half of the plane are those who did not have Swiss nationality (10.3\%), had only one nationality each (7.3\%) and completed their secondary education within non-EU countries (6.5\%). At the bottom are those who pursued their secondary education in Switzerland (16.7\%), had Swiss nationality $(16.0 \%)$ and possessed two (8.5\%) or even three or more nationalities each (4.6\%). The second axis contrasts the students who were rooted in Switzerland by nationality or school with those who came to Switzerland only for their tertiary education.

\subsection{Five configurations of cosmopolitan capital}

We retained five clusters for interpretation that represent various types of cosmopolitan capital.

Figure 2: Five clusters of SHMS students 
Individuals - Axis $1 \& 2$

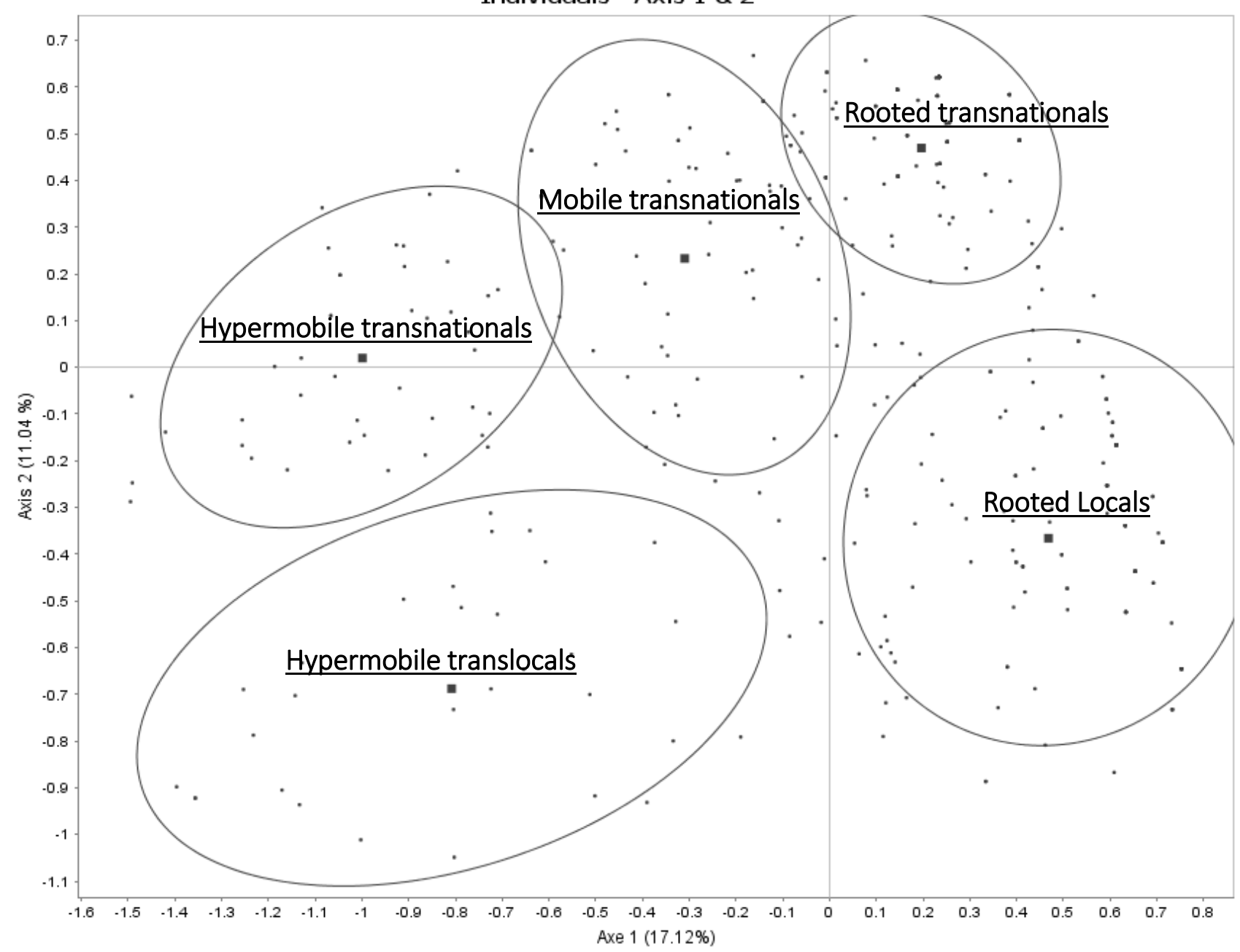

Almost none of the rooted transnationals $(30.7 \%, n=117)$ was Swiss. They mostly attended secondary establishments with local students (99.1\% versus $74.0 \%$ in the overall sample) and were taught with national languages (96.6\% versus $74.3 \%)$. The majority of them had one nationality each, and all of them had sedentary school careers. Furthermore, rooted transnationals were more likely to have obtained national academic diplomas (88.9\% versus $66.9 \%)$ from public institutions $(69.2 \%$ versus $56.4 \%)$. A third of the cluster (35.9\%) came from neighbouring countries or from non-EU countries (45.3\%). Finally, 43.6\% could speak two languages fluently-their mother tongues and English - versus $36.0 \%$. It seems as if these students came for their first long-term stays abroad to study at Swiss hotel schools. Previously, they were rooted in their countries of origin, where they pursued mainly national and public educational trajectories.

In addition, hardly any of the mobile transnationals $(15.2 \%, n=58)$ possessed Swiss passports $(5.2 \%$ versus $39.1 \%$ ). Moreover, twice as many students came from non-EU countries (60.3\% versus $32.3 \%$ ). Nearly two-thirds of them attended private establishments during their secondary education (against 42.5\%). A quarter had English as a teaching language (against 17.6\%), and a third had obtained an 
international academic diploma (against 19.7\%). Regarding their mobility, 27.6\% (against 16.3\%) moved to another country once, and $17.2 \%$ did it three times or more (against $10.2 \%$ ). In comparison with the rooted transnationals, the mobile transnationals were more likely to have experienced transnational migrations and to have been integrated into private and international school systems.

The majority of rooted locals $(34.9 \%, n=133)$ were Swiss and had been educated in Switzerland at the secondary level. Most of them had studied in public establishments ( $83.5 \%$ versus $56.4 \%$ ), where they were taught with national languages (91.7\% versus $74.3 \%$ ), and most of them had studied with other local students (86.5\% versus $74.0 \%$ ). A quarter of them obtained vocational secondary diplomas instead of academic ones. In particular, having multiple citizenships was widespread in this group: Nearly half of them had two nationalities (versus $32.0 \%$ ), and $8.3 \%$ had three or more nationalities (versus 5.2\%). In addition, almost all of them had stayed in the same country during their primary and secondary education (96.2\% versus $83.5 \%$ ). The rooted locals differed from the rooted transnationals because they had stayed in their home countries (Switzerland) for their higher education. However, they had inherited a form of cosmopolitan capital due to their geographically diverse family backgrounds.

Most of the hypermobile transnationals $(11.3 \%, n=43)$ attended international and English-teaching private schools in secondary education. Two-thirds had obtained international academic diplomas (versus 19.7\%). Half of them (versus 16.8\%) had transnational school careers. Many experienced relocations during their childhoods: They were three times more likely than our sample to have moved twice before turning 18 years old: One-third moved once, and nearly a quarter migrated three times or more. They spent their secondary education periods mostly outside of the European Union $60.5 \%$ versus $32.3 \%$ ) or in non-neighbouring EU countries (27.9\% versus $10.2 \%)$. In addition, $18.6 \%$ (versus 8.1\%) completed their secondary education in foreign languages that were not English. These hypermobile transnationals differed from mobile transnationals because twice as many of them had international academic diplomas and had been very mobile during their childhoods: $70.7 \%$ of them had moved at least once before turning 18 years old ( $32.6 \%$ once, $27.9 \%$ twice and $10.8 \%$ three times or more). 
Nearly all of the hypermobile translocals ${ }^{6}(7.9 \%, n=30)$ studied among foreign pupils during their secondary education periods, two-thirds held international academic diplomas and half of them had been taught in English. Three-quarters of them (versus 16.5\%) had transnational school careers. Forty percent of these students had moved out of a country three or more times during their childhoods. Moreover, two-thirds (versus $32.0 \%$ ) had two nationalities, and $20.0 \%$ had three or more nationalities (versus 5.2\%). Their particularity, in comparison with the mobile or hypermobile transnational students, was that $60.0 \%$ of them had completed secondary education in Switzerland, and a similar portion (60.0\%) had Swiss nationality (against 39.1\%). Consequently, these students seemed to have been endowed with a particularly high volume of cosmopolitan capital: 36.7\% (against 19.9\%) spoke four or more languages fluently, and $20.0 \%$ (against $8.1 \%$ ) had been taught in foreign languages other than English while in secondary education.

The members of the two rooted clusters were not mobile during their childhoods and possessed smaller amounts of cosmopolitan capital compared with the members of the three mobile clusters. The members of the three mobile clusters experienced transnational mobility during their childhoods. Due to the mobile lifestyles of their families, most of these students attended private and often international schooling during the primary and secondary stages of their education. These schools offered them flexibility, continuity and recognition in several places and consequently provided them with relatively stable schooling despite the frequent relocations. In comparison, the hypermobile translocals often came from nationally mixed families with at least one Swiss parent. They were both transnationally mobile and locally anchored, a double characteristic that is historically typical of elites (Wagner 2005, 1998). The various configurations of cosmopolitan capital reflected the family and school trajectories. Students with mixed national origins had most likely grown up in transnational, multilingual family networks in which relationships beyond national borders were cultivated. Other students followed the transnational trajectories of their parents and thereby had regular experiences of mobility during their childhoods. In this way, they acquired their own mobility capital and institutionalised it via international schooling. Familial and educational cosmopolitan capital were thus often cumulative.

Our results showed that international educational institutions attract students from various geographical origins and that these students have varying forms of inherited and acquired

\footnotetext{
${ }^{6}$ Hypermobile translocals not only have been frequently mobile during their childhoods but also they benefit from a local anchor in Switzerland, where they can easily settle down or top off. According to Brickell and Datta (2011), translocality is their "situatedness during mobility."
} 
cosmopolitan capital. A first cleavage contrasts those experiencing transnational student mobility with those who benefit from local opportunities to internationalise their educational profiles. Nuances distinguish groups with various amounts of cosmopolitan capital, depending on the spheres in which cosmopolitan dispositions were acquired.

\subsection{The social origins of the five fractions of SHMS students}

How are these configurations of cosmopolitan capital related to social and occupational backgrounds? In this section, we compare both the education levels and the employment positions of the parents, explore the types of capital of the parents and formulate a series of interpretations in terms of strategies of the acquisition, reproduction and conversion of international capital.

The characteristics of the social origins of SHMS students

SHMS students come from particularly privileged backgrounds (Table 3). In comparison with students from Swiss universities, which are already socially narrowly selected, a considerable portion of them come from society's upper echelons. Parents of SHMS students work in the corporate world and possess a high amount of economic capital. Intellectual professions, endowed with high amounts of cultural capital, are much less present in the SHMS student population.

Table 3: Occupational categories of the parents of SHMS students and Swiss university students (\%)

\begin{tabular}{|c|c|c|}
\hline & $\begin{array}{l}\text { Parents of } \\
\text { SHMS } \\
\text { Students } \\
(2016)\end{array}$ & $\begin{array}{c}\text { Parents of } \\
\text { students in } \\
\text { Swiss } \\
\text { Universities } \\
\text { (2016) }\end{array}$ \\
\hline Executive / Top-level Manager & 46.5 & 4.0 \\
\hline Liberal Professions & 17.2 & 11.0 \\
\hline Other Self-employed & 11.9 & 15.0 \\
\hline Intellectual professions \& Mid-level Manager & 17.2 & 34.0 \\
\hline $\begin{array}{l}\text { Intermediate professions \& Lower-level Manager } \\
\text { / Employee }\end{array}$ & 7.2 & 36.0 \\
\hline Total & 100.0 & 100.0 \\
\hline
\end{tabular}

Clearly, more SHMS students come from higher managerial and entrepreneurial milieus (46.5\%) than do students at Swiss universities (4\%). Although the same is true, albeit in a much more modest way, for professionals (17.2\% versus $11 \%$ ), the parents of SHMS students are underrepresented in the middle and lower categories of the class structure. In comparison, the fathers of students attending Swiss universities are more likely to be employed in intellectual or intermediate professions. This opposition between the "economic pole" and the "cultural pole" is a classic contrast in studies on the 
upper classes (Bourdieu, 1982). SHMSs seem to be part of business elites' mode of reproduction, rather than the preferred schooling institutions of the cultural and intellectual elites. Therefore, SHMSs can be viewed as an extension of the proliferation of management and business schools (Bourdieu 1989; Khurana 2007) to reproduce corporate upper classes and their power in the global economic field.

\section{Social origins according to the five clusters}

SHMS students come from particularly privileged and business-oriented families, but what are the differences among them? Can we discern differences among the five configurations of cosmopolitan capital in terms of social background?

Table 4: Parent's occupational categories of the five clusters of SHMSs' students

\begin{tabular}{|c|c|c|c|c|c|c|}
\hline \multirow[b]{2}{*}{ Clusters } & \multicolumn{5}{|c|}{ Occupational category of the "head of the household" parent (\%) } & \multirow[t]{2}{*}{$\mathbf{N}$} \\
\hline & $\begin{array}{l}\text { Entrepreneur / } \\
\text { Top Executive }\end{array}$ & $\begin{array}{c}\text { Liberal } \\
\text { Profession }\end{array}$ & $\begin{array}{l}\text { Other Self- } \\
\text { Employed }\end{array}$ & $\begin{array}{l}\text { Intellectual } \\
\text { Profession / } \\
\text { Mid-Level } \\
\text { Manager }\end{array}$ & $\begin{array}{c}\text { Intermediate } \\
\text { Profession / } \\
\text { Lower-Level } \\
\text { Manager / } \\
\text { Employee }\end{array}$ & \\
\hline Rooted transnationals & 50.0 & 12.7 & 8.2 & 22.7 & 6.4 & 110 \\
\hline Mobile transnationals & 54.7 & 22.6 & 7.5 & 13.2 & 1.9 & 53 \\
\hline Rooted locals & 27.6 & 24.4 & 18.9 & 17.3 & 11.8 & 127 \\
\hline $\begin{array}{l}\text { Hypermobile } \\
\text { transnationals }\end{array}$ & 82.9 & 4.9 & 4.9 & 7.3 & 0.0 & 41 \\
\hline $\begin{array}{l}\text { Hypermobile } \\
\text { translocals }\end{array}$ & 50.0 & 10.0 & 13.3 & 16.7 & 10.0 & 30 \\
\hline Total & 46.5 & 17.2 & 11.9 & 17.2 & 7.2 & 361 \\
\hline
\end{tabular}

Crossing the cluster with occupational categories shows dramatic differences within the space of SHMS students (Table 4). A total of $82.9 \%$ of the hypermobile transnationals and half of the hypermobile translocals came from backgrounds in executive management; only $27.6 \%$ of the rooted locals had fathers who were top-tier managers. In addition, $24.4 \%$ of rooted locals and $22.6 \%$ of mobile transnationals had fathers who worked as liberal professionals. This proportion was three times lower for the hypermobile transnationals (4.9\%). Therefore, we hypothesise that the accumulation and reproduction of cosmopolitan capital also depends on the socio-economic background of the parents and the typical mobility patterns of their occupations. Entrepreneurs and top managers are frequently mobile and must relocate throughout their careers (Bühlmann et al. 2018). On the other hand, liberal professions and smaller self-employed are anchored in specific places to establish professional renown 
and stable client bases. The "lack" of mobility of rooted locals during their childhoods can be explained by their parents' sedentary professional careers. Examining the parents' levels and types of education can provide insight into the reproduction and strategic use of cosmopolitan capital.

Table 5: Parent's educational levels of the five clusters of SHMs' students

\begin{tabular}{|c|c|c|c|c|c|c|}
\hline \multirow[b]{2}{*}{ Clusters } & \multicolumn{5}{|c|}{$\begin{array}{l}\text { "Head of the household" parent educational levels and } \\
\text { disciplines (\%) }\end{array}$} & \multirow[t]{2}{*}{$\mathbf{N}$} \\
\hline & $\begin{array}{c}\text { Human / } \\
\text { soc } \\
\text { science }\end{array}$ & Eco & $\begin{array}{l}\text { Law / } \\
\text { medicine }\end{array}$ & $\begin{array}{c}\text { Engin/ } \\
\text { Nat } \\
\text { sciences }\end{array}$ & $\begin{array}{l}\text { No } \\
\text { university }\end{array}$ & \\
\hline Rooted transnationals & 9.1 & 16.4 & 17.3 & 16.4 & 40.9 & 110 \\
\hline Mobile transnationals & 5.7 & 20.8 & 24.5 & 18.9 & 30.2 & 53 \\
\hline Rooted locals & 11.8 & 11.0 & 18.9 & 11.0 & 47.2 & 127 \\
\hline Hypermobile transnationals & 7.3 & 26.8 & 7.3 & 31.7 & 26.8 & 41 \\
\hline Hypermobile translocals & 13.3 & 10.0 & 10.0 & 20.0 & 46.7 & 30 \\
\hline Total & 9.7 & 15.8 & 17.2 & 16.9 & 40.4 & 361 \\
\hline
\end{tabular}

Table 5 shows that the children of parents who studied economics or business management (natural and technical sciences, respectively) are more prevalent in the mobile clusters. The accumulation of cosmopolitan capital during childhood-and especially by moving across countries-seems to be influenced by the types of education and occupations that the parents have. When parents have been trained in management or engineering, their children are more likely to accumulate cosmopolitan capital.

To explore the role of parents' education and occupational categories in the accumulation and reproduction of cosmopolitan capital, we conducted a multinomial regression analysis (Table 6). 
Table 6: Multinomial regression: membership in the five clusters of cosmopolitan capital (OR)

\begin{tabular}{|c|c|c|c|c|c|}
\hline & & $\begin{array}{c}\text { Mobile } \\
\text { Transnationals }\end{array}$ & $\begin{array}{c}\text { Hypermobile } \\
\text { Transnational } \\
\text { s }\end{array}$ & $\begin{array}{c}\text { Rooted } \\
\text { Transnationals }\end{array}$ & $\begin{array}{c}\text { Hypermobile } \\
\text { Translocals }\end{array}$ \\
\hline \multirow[t]{2}{*}{$\begin{array}{l}\text { Entrepreneurs / } \\
\text { top executives }\end{array}$} & No & -- & -- & -- & -- \\
\hline & Yes & $2.97^{* *}$ & $9.92^{\star \star *}$ & $2.43^{\star *}$ & $2.41^{*}$ \\
\hline \multirow[t]{5}{*}{ Education } & No University & -- & -- & -- & -- \\
\hline & $\begin{array}{l}\text { Human / social } \\
\text { sciences }\end{array}$ & 0.80 & 0.78 & 0.78 & 1.11 \\
\hline & Eco / Business & $3.07^{*}$ & 2.94 & 1.51 & 0.87 \\
\hline & Law / Medicine & $2.77^{*}$ & 0.8 & 1.14 & 0.64 \\
\hline & $\begin{array}{l}\text { Engineering and } \\
\text { Natural sciences }\end{array}$ & 2.78 & $3.50^{*}$ & 1.47 & 1.76 \\
\hline \multirow[t]{2}{*}{ Sex } & Female & -- & -- & -- & -- \\
\hline & Male & 0.99 & 1.18 & 0.83 & 1.10 \\
\hline Intercept & & $0.14^{\star \star *}$ & $0.05^{\star * *}$ & $0.57^{*}$ & $0.15^{\star \star \star}$ \\
\hline
\end{tabular}

${ }^{\star \star \star} p \leq 0.001 ;{ }^{\star \star} p \leq 0.01 ;{ }^{\star} p \leq 0.05$; reference category: rooted locals

Compared with the rooted locals (reference category), all of the clusters have more frequently parents who are entrepreneurs or the top executives of large firms. These children experienced family lives characterised by high numbers of transnational moves, which allowed them to accumulate a high amount of cosmopolitan capital. An analysis of the type and level of education confirms this surplus of inherited economic capital: The members of the cluster mobile transnational have significantly higher numbers of parents who studied economics, business, law or medicine. Among the cluster of hypermobile transnational students in particular, parents with degrees in engineering and natural sciences are widespread. These educational credentials seem to lead to occupations that allow for children to experience more international mobility during their childhoods, thereby contributing to the accumulation of cosmopolitan capital.

\section{Conclusion: acquisition versus certification of cosmopolitan capital}

In this article, we examined how the internationalisation of higher education offers new opportunities for strategies of the social mobility and reproduction of specific groups in the middle and upper classes. We argued that cosmopolitan capital - skills, knowledge and dispositions acquired via transnational experiences or international environments - has become a new (or at least heightened) resource that can be acquired, converted and reinforced during one's educational trajectory. SHMSs, which are generally private international establishments of tertiary education, were chosen as a heuristic case in which to study the use of this new form of capital. We conducted a survey with 381 students from six SHMSs, and we identified five configurations of cosmopolitan capital: rooted locals (34.9\%), rooted 
transnationals $(30.7 \%)$, mobile transnationals $(15.2 \%)$, hypermobile transnationals $(11.3 \%)$ and hypermobile translocals (7.9\%). Compared with students of Swiss universities, most of the SHMS students came from privileged backgrounds. A multinomial regression showed that the mobile students more frequently had parents from the economic class fraction, characterised by a high amount of economic capital and studies in business-related disciplines, such as economics or engineering.

What do these results mean for the intentional or unintentional strategies of social (re)production in the context of the internationalisation of higher education? We posit that for rooted students (rooted locals or rooted transnationals), attending SHMSs corresponds to the strategy of the conversion of familial economic capital into international educational and occupational capital. These rooted students are from the economic pole of the upper-middle classes of their countries of origin. For rooted transnationals, international management degrees potentially represent distinctions in their national contexts, and they offer them social and geographical mobility. Rooted locals benefit from local opportunities to internationalise their educational profiles and to gain access to the international social group. In contrast, mobile students (mobile transnationals, hypermobile transnationals and mobile translocals) already possess a high amount of inherited cosmopolitan capital due to their fathers' international and managerial careers. We can make the hypothesis that attending SHMSs constitutes for them the continuation of a mobile family trajectory and an international educational curriculum. They certify and legitimise their inherited cosmopolitan capital by earning degrees from SHMSs. In accordance with Bourdieu and Passeron $(1970,1964)$, we posit that these cosmopolitan students choose training that will perpetuate their inherited economic, cultural and social capital. Their choice of a hospital management strategy seems to be part of a social reproduction strategy that aligns with an inherited cosmopolitan lifestyle. 


\section{Appendix}

Table 7: Active variables and categories used in MCA and their contributions to the axis

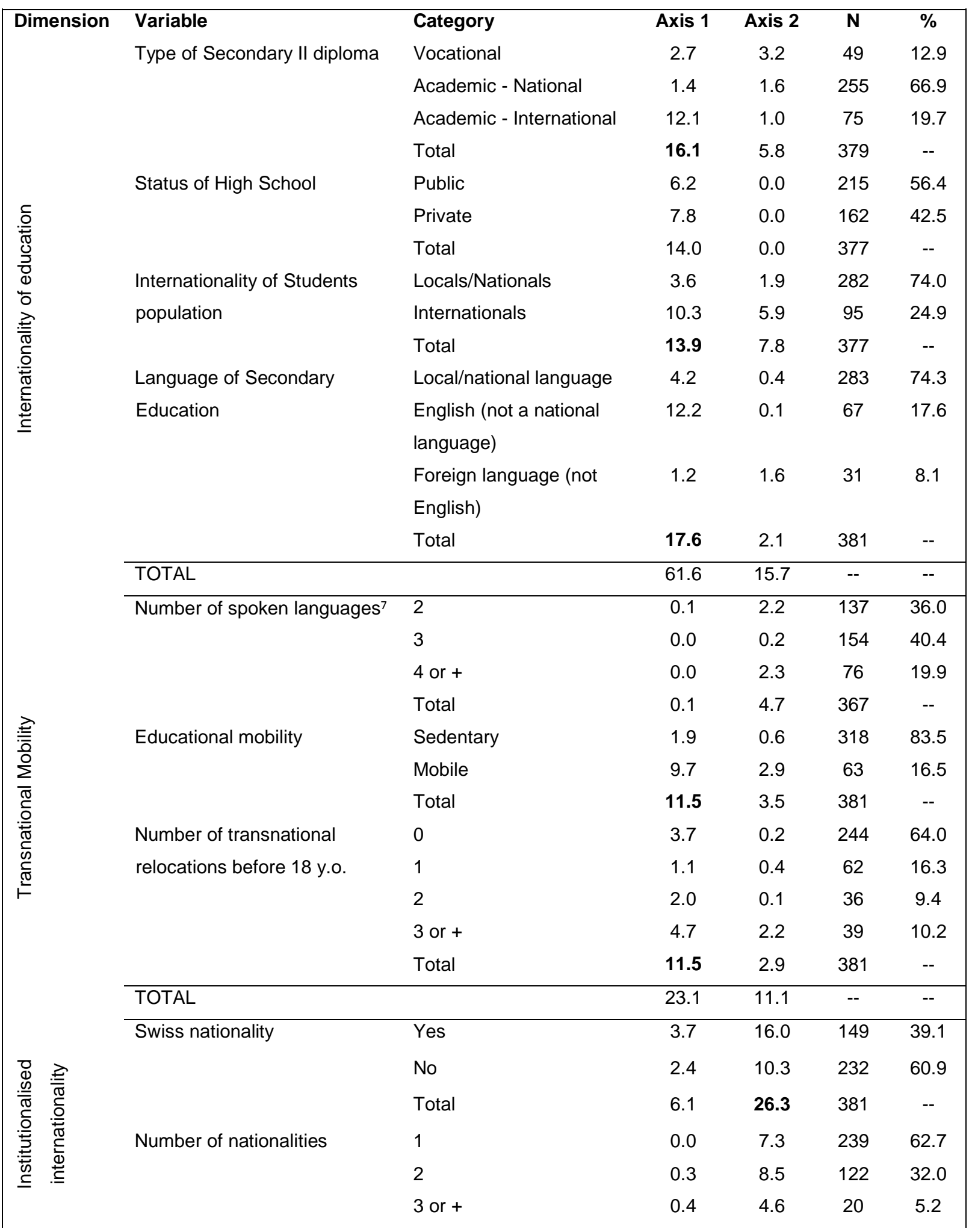

\footnotetext{
${ }^{7}$ The category " 1 language spoken" has only $3.7 \%$ of response in our sample. It has been defined as an "illustrative modality", which doesn't contribute to the creation of the geometrical space.
} 


\begin{tabular}{llcccc} 
& Total & 0.7 & $\mathbf{2 0 . 4}$ & 381 & -- \\
Country of secondary & Switzerland & 3.4 & 16.7 & 137 & 36.0 \\
education & Neighbour country of & 0.5 & 2.2 & 76 & 19.9 \\
& $\begin{array}{l}\text { Switzerland } \\
\text { Other member country of }\end{array}$ & 1.1 & 1.0 & 39 & 10.2 \\
& EU & & & & \\
& No-member country of & 3.3 & 6.5 & 123 & 32.3 \\
& EU & & & & \\
& Total & 8.3 & $\mathbf{2 6 . 4}$ & 375 & -- \\
\hline TOTAL & 15.1 & 73.1 & -- & -- \\
\hline
\end{tabular}

\section{References}

Almeida, J., Robson, S., Morosini, M., \& Baranzeli, C. (2018). Understanding Internationalization at Home: Perspectives from the Global North and South. European Educational Research Journal, 1-18.

Altbach, P. G. (1999). Private higher education: Themes and variations in comparative perspective. Prospects, 29(3), 310.

Altbach, P. G., Reisberg, L., \& Rumbley, L. E. (2009). Trends in Global higher Education : Tracking an Academic Revolution. A report prepared for the UNESCO 2009 World Conference on Higher Education. Paris: UNESCO.

Beelen, J., \& Jones, E. (2015). Redefining Internationalization at Home. In A. Curaj, L. Matei, R. Pricopie, J. Salmi, \& P. Scott (Eds.), The European HIgher Education Area. Between Critical Reflections and Future Policies (pp. 59-72). New York: Springer.

Bertron, C. (2018). Des enfants des élites post-soviétiques dans les pensions suisses. Actes de la recherche en sciences sociales, 225(5), 14-27.

Börjesson, M. (2017). The global space of intenational students. Journal of Ethnic and Migration Studies, 43(8), 1256-1275.

Bourdieu, P. (1979). La Distinction. Paris: Les Editions de Minuit.

Bourdieu, P. (1989). La Noblesse d'Etat. Grandes écoles et esprit de corps. Paris: Les éditions de minuit.

Bourdieu, P. (1993). Sociology in Question. London: Sage.

Bourdieu, P., \& Passeron, J.-C. (1964). Les héritiers : les étudiants et la culture (Le sens commun). Paris: Les Editions de Minuit.

Bourdieu, P., \& Passeron, J.-C. (1970). La reproduction. Eléments pour une théorie du système d'enseignement. Paris: Editions de Minuit.

Brickell, K., \& Datta, A. (2011). Translocal geographies. Spaces, places, connections. Surrey: Ashgate.

Brooks, R., \& Waters, J. (2015). The Hidden Internationalism of Elite English Schools. Sociology, 49(2), 212-228.

Bühlmann, F., Mach, A., \& David, T. (2013). Cosmopolitan Capital and the Internationalisation of the Field Business Elites : Evidence from the Swiss Case. Cultural Sociology, 7, 211-229.

Bühlmann, F., Ravasi, C., \& Davoine, E. (2018). European Top Management Careers: a Field-Analytical Approach. European Societies, 20(3), 453-477.

Carlson, S. (2013). Becoming a Mobile Student - a Processual Perspective on German Degree Student Mobility. Population, space and place, 19, 168-180.

Draelants, H., \& Ballatore, M. (2014). Capital culturel et reproduction scolaire. Un bilan critique. Revue française de pédagogie, 186.

Dugonjic-Rodwin, L. (2014). Les IB Schools, une internationale élitiste: émergence d'un espace mondial $d^{\prime}$ enseignement secondaire au XXe siècle. Université de Genève, Genève. 
Findlay, A. (2010). An Assessment of Supply and Demand---Side Theorizations of International Student Migration. International Migration, 49(2), 162-190.

Findlay, A., King, R., Smith, F. M., Geddes, A., \& Skeldon, R. (2012). World class? An investigation of globalisation, difference and international student mobility. Transactions of the Institute of British Geographers, 31(1), 118-131.

Forsberg, H., Palme, M., \& Börjesson, M. (2017). Le marché de l'éducation et la structure sociale : la transformation de l'enseignement secondiare supérieur suédois à la veille des réformes du libre choix. Esprit Critique : revue internationale de sociologie et de sceinces sociales, 27(1), 2336.

Hall, S., \& Appleyard, L. (2011). Trans-local academic credentials and the (re)production of financial elites. Globalisation, Societies and Education, 9(2), 247-264.

Igarashi, H., \& Saito, H. (2014). Cosmopolitanism as Cultural Capital : Exploring the Intersection of Globalization, Education and Stratification. Cultural Sociology, 1-18.

Kaufmann, V., Bergman, M. M., \& Joye, D. (2004). Motility: mobility as capital. International Journal of Urban and Regional Research, 28(4), 745-756.

Khan, S. R. (2011). Privilege : The Making of an Adolescent Elite at St. Paul's School. Princeton: Princetong University Press.

Khurana, R. (2007). From Higher Aims to Hired Hands. Princeton: Princeton University Press.

King, R., Findlay, A., Ahrens, J., \& Dunne, M. (2011). Reproducing Advantage: The Perspective of English School Leavers on Studying Abroad. Globalisation, Societies and Education, 9, 161-181.

Le Roux, B. (2014). Analyse géométrique des données multidimensionnelles. Paris: Dunod.

Leung, M., \& Waters, J. (2013). British degrees made in Hong Kong: an enquiry into the role of space and place in transnational education. Asia Pacific Education Review, 14, 43-53.

Levatino, A. (2017). Transnational higher education and international student mobility: determinants and linkage. Higher Education, 73(637-653).

Marginson, S. (2006). Dynamics of National and Global Competition in Higher Education. Higher Education, 52(1), 1-39.

Mitchell, D. E., \& Nielsen, Y. S. (2012). Internationalization and Globalization in Higher Education. In H. Cuadra-Montiel (Ed.), Globalization. Education and Management Agendas: Intech-------open.

Murphy-Lejeune, E. (2002). Student Mobility and Narrative in Europe. The New Strangers. London: Routledge.

Nogueira, M. A., \& Aguiar, A. (2008). La formation des élites et l'internationalisation des études : peuton parler d'une "bonne volonté internationale" ? Education et sociétés, 21(1), 105-119.

Petzold, K., \& Peter, T. (2015). The social norm to study abroad: determinants and effects. Higher Education, 69, 885-900.

Resnik, J. (2012a). The Denationalization of Education and the Expansion of the International Baccalaureate. Comparative Education Review, 56(2), 248-269.

Resnik, J. (2012b). Sociology of International Education. An Emerging Field of Research. International Studies in Sociology of Education,, 22(4), 291-310.

Riano, Y., Lombard, A., \& Piguet, E. (2018). How to explain migration policy opennes in times of closure? The case of international students in Switzerland. Globalisation, Societies and Education, 16(3), 295-307.

Robson, S. (2011). Internationalization: a Transformative Agenda for Higher Education? Teachers and Teaching, 17(6), 619-630.

Robson, S., Almeida, J., \& Schartner, A. (2018). Internationalization at home: time for review and development? European Journal of Higher Education, 8(119-35).

Sayad, A. (1991). L'immigration ou les paradoxes de l'altérité. Bruxelles: De Boeck Editions.

Wagner, A.-C. (1998). Les nouvelles élites de la mondialisation. Pari: Presses Universitaires de France.

Wagner, A.-C. (2005). Les élites managériales de la mondialisation : angles d'approche et catégories d'analyse. Entreprises et histoires, 41, 15-23.

Wagner, A.-C. (2011). Les classes dominantes à l'épreuve de la mondialisation. Actes de la recherche en sciences sociales, 190, 4-9. 
Wagner, A.-C., \& Réau, B. (2015). Le capital international : un outil d'analyse de la reconfiguration des rapports de domination. In J. Siméant (Ed.), Guide de l'enquête globale en sciences sociales (pp. 33-46). Paris: CNRS éditions.

Waters, J. (2006). Geographies of cultural capital: education, international migration and family strategies between Hong Kong and Canada. Transactions of the Institute of British Geographers, 31(2), 179-192.

Waters, J. (2012). Geographies of International Education: Mobilities and the Reproduction of Social (Dis)Advantage. Geography Compass, 6(3), 123-136.

Waters, J., Brooks, R., \& Pimlott-Wilson, H. (2011). Youthful Escapes? British Students, Overseas Education and the Pursuit of Happiness. Social \& Cultural Geography, 12, 455-469.

Weenink, D. (2007). Cosmopolitan and Estbalished Resources of Power in the Education Arena. International Sociology, 22(4), 492-516.

Weenink, D. (2008). Cosmopolitanism as a Form of Capital Parents Preparing their Children for a Globalizing World. Sociology, 42, 1089-1106.

Willoughby, J. (2008). Let a Thousand Models Bloom : Forging Alliances with Wester Universities and the Making of the New Higher Educational System in the Gulf. Department of Economics Working Paper Series, 1.

Xiang, B., \& Shen, W. (2009). International student migration and social stratification in China. International Journal of Educational Development, 29, 513-522. 